\title{
Model of Policy Collaboration in the Field of Health Reviewed From the Perspective of Learning Policies in South Sulawesi
}

\author{
Aslinda*s \\ Departemen of State Administration \\ Faculty of Sosial Science \\ Universitas Negeri Makassar \\ Makassar, Indonesia \\ aslinda@unm.ac.id
}

\author{
Muhammad Guntur \\ Departemen of State Administration \\ Faculty of Social Science \\ Universitas Negeri Makassar \\ Makassar, Indonesia \\ m.guntur@unm.ac.id
}

\author{
Muh. Rizal \\ Departemen of Bussines \\ Adminsitration \\ faculty of sosial science \\ Universitas Negeri Makassar \\ Makassar, Indonesia \\ rizalsuyuti@unm.ac.id
}

\begin{abstract}
Development in the health sector is part of national policy development so development must be a priority to ensure a healthy community life. The purpose of this study is to find out whether there is government collaboration in the health sector and whether there is learning from the health policy program in South Sulawesi. The design of this study uses a descriptive qualitative research design with the assumption that policy learning involves a complex mix of facts and values that are difficult to measure empirically. The results of the study showed that the South Sulawesi provincial government had collaborated with various cross-sectoral organizations such as collaboration with Regency / City government, JICA international organizations, and cooperation with various social organizations. Another result is that policy learning has a significant role in developing health development in the province of South Sulawesi.
\end{abstract} Sector

Keywords: Policy collaboration, Policy learning, Health

\section{INTRODUCTION}

When the world entered the 21 st century, there were great changes in a short time. The process of change provides a number of challenges that must be answered by the Indonesian people. There are challenges in the form of opportunities that must be utilized but there are also obstacles that must be overcome so that they can provide benefits. In line with these developments, the public policy states that there are various demands for development in society that require strategic public policies to deal with various development issues that are both internal and external [1].

Development in the health sector is a part of national policy development [2]. Health development is the key to successful development in other fields because health is a primary and fundamental human need so that the direction of development must guarantee a healthy community life. Health is one element of public welfare which is the goal of the state as mandated by Pancasila and the 1945 Constitution of The Republic of Indonesia as the national constitution of Indonesia. Health Law No. 36 of 2009 articles 4 and 5 also state that everyone has the same rights in obtaining access to resources in the health sector, the right to obtain safe, quality and affordable health services and each person has the right to independently and responsibly determine for himself the health services needed for him/her [3].

In realizing the overall health development and improve the level of public health, the government has established decentralized regulations through Law of The Republic of The Indonesia number 23 year 2014, Ministerial Regulation number 38 year 2007 concerning Division of Central Government Affairs and Regional Government Affairs, and Law of The Republic of The Indonesia number 33 year 2004 concerning Financial Balance between Central and Regional Governments. The transfer of central policies to regional governments has encouraged the collaboration of each region with non-government institutions in the health sector. Local governments are given the authority to develop health systems in the regions in accordance with the needs of their communities. Even though government affairs in the health sector remain a joint function (concurrent function) [4].

The goals and direction of health development policies in South Sulawesi are based on the principles of decentralization, de-concentration, and co-administration. To carry out this task, the Department of Health has the functions of regulating, guiding and supervising which includes health services, disease control, and environmental health, public health as well as health workforce resources and health technology. To achieve the goals and direction of the health development policy, the central government and the provincial government of South Sulawesi have collaborated with international parties to produce deconcentrated funds as much as Rp.45,625,550,000, consisting of pure rupiahs and companions of Rp.25,796,369,000 --, and PHLN as much as Rp.19,829,181,000-, while the regional health financing budget for the province of South Sulawesi is Rp. 27,480,221,515, - consisting of direct expenditure of Rp. $10,200,000,000$ and indirect funding of Rp. 17,280,221,515,- (South Sulawesi Province Health Service Strategic Plan 2013-2018) [5].

To realize the goals of health development in South Sulawesi, the government, in this case, the Governor of South Sulawesi Province, has cooperated with all regencies and cities in the region of South Sulawesi Province to 
jointly solve problems faced by the community, especially in the health sector such as the difficulty of the community. in accessing health services, not yet optimal empowerment of village/regency groups or forums, lack of infrastructure, lack of health workers, maternal mortality rate (MMR), infant mortality rate (IMR) and community nutritional status are still fluctuating, minimum service standard management (SPM)), and Millennium Development Goals (MDGs). In addition, in general, the morbidity rate due to infectious diseases can be reduced but infectious diseases and infectious diseases especially ATM (AIDS/HIV, Tuberculosis, and Malaria) are still high and require serious efforts to resolve them. Given the health problems associated with public policy, it is necessary to analyze health development policies based on public policy perspectives (South Sulawesi Province Health Service 20132018) [6].

Analysis of public policy is dominated by the traditional approach, namely policy cycles. This traditional approach treats the public policy as distinctive stages. Models of the stages of the policy cycle that are commonly found in the traditional public policy literature are policymaking, policy implementation, and policy impact (Wilson, 2006). Since the $1980 \mathrm{~s}$, the traditional policy cycle approach has drawn criticism because it is considered unrealistic. At the policy stage, in addition to overlapping, it is also often inseparable and in practice aspects of policy problems and policy solutions are often present together [7].

Related to the above problems, this study tries to uncover how the collaboration model in health development policy programs is viewed from the perspective of policy learning in South Sulawesi Province. Policy learning has been a major area of concern for public policy thinkers in public administration and political science since the relevant concept was adopted by Heclo in 1974. The perspective of policy learning covers distinctive stages in public policy so that it can turn policy problems into policy solutions if in policy implementation activities of political actors or policymakers can take lessons from the failures of their own policies and other jurisdictional policies [8].

\section{METHODOLOGY}

This research was located in Wajo Regency, South Sulawesi with the consideration that Wajo Regency is a more advanced district in terms of policy learning compared to the other two districts namely Bulukumba Regency and Barru Regency within the scope of South Sulawesi Province which has organized poverty reduction programs through the health sector by involving national and international cooperation in the field of health care in South Sulawesi.

This research focuses on the collaboration model in the healthy development policy program in terms of policy learning perspectives in South Sulawesi Province by utilizing case studies and using qualitative descriptive approaches. The use of qualitative research design is based on the assumption that policy learning involves a complex mix of facts and values that are difficult to measure empirically and in control as conducted by quantitative researchers. The complex mix of facts and values can only be investigated more accurately by using a qualitative approach, which is often recommended for post-normal science [9] .The type of design used in this study is a case study. Case study is a typical design of qualitative researchers[10][11]. The informants in this study are: (a). Head of South Sulawesi Province Health Service, (b). SKPD involved in health development program policies (c). Communities targeted by health programs, (d). Village / Village Head related to health program policies, (e). Community Organization Groups in rural/urban villages involved with health development program policies, (f) as well as several foreign actors who have collaborated with the government of South Sulawesi Province. Data is collected and analyzed using data reduction. The data that have been collected are then presented in a descriptivequalitative method and used to draw conclusions [12][13].

\section{RESULT AND DISCUSSION}

\section{A. Health Program in South Sulawesi}

The issuance of Law of The Republic of The Indonesia number 22 year 1999 concerning Regional Government makes the health sector entirely in the hands of local governments. To support the spirit of regional autonomy, the government has issued various policies related to healthy development such as regulation number 1 / Menkes / Per / SK / VII / 2008 regarding Provision of Minimum Services in the health sector in districts/cities and in 2015 has set 80 $\%$ of villages to become Active Alert Village (DSA). Thus, the Minimum Service Standards (SPM) target must be interpreted as achieving $80 \%$ of villages into active-standby villages. The government's move to strengthen the acceleration of active villages and villages throughout Indonesia through a policy in the form of health minister number 29 / Menkes / SK / X / 2010 concerning of ActiveStandby Villages)

One illustration of the health program is Prime Health which has been implemented in South Sulawesi Province. The program is the main focus of this research to see how the learning outcomes of the health program in South Sulawesi. There are 115 villages in three districts that have implemented a prime health program.

Prime Health is one of the community empowerment programs that aims to involve various levels of organization from the village level up to the provincial level to address basic community health problems, such as environmental cleanliness, infrastructure, and water supply. The implementation of Prime Health has been carried out through various levels of socialization with budgets originating from the Grand Block and JICA, Local Government Budget , and Non-Governmental Organizations. This proves the involvement of various agencies to collaborate in the Prime Health program. 


\section{B. Health Collaboration Program in South Sulawesi}

Actually organizing system has been done from the beginning, but the speakers here focuses particularly on organizing in the management of facilities and services to the exclusion of other things that are also spelled organizing system. Organizing a process of management in the form of supervision and assignment, this is due to the division of labor vertically and horizontally, but it all can not be separated from the procedures, processes and objectives to be achieved in the framework of cooperation, which begins Collaboration is a way to respond to changes that require problems so as to improve the quality of health development in South Sulawesi. Various forms of collaboration that have been produced can be described as following:

\section{Collaboration of government and community}

The program of activities that have been successfully implemented in collaboration with the government and the community in the health sector in South Sulawesi can be followed by the table below:

Table 1: Program of activities that have been successfully implemented in collaboration with the government and the community in the health sector in South Sulawesi

\begin{tabular}{|c|c|c|c|}
\hline No & Program & Collaboration & Activity \\
\hline 1 & $\begin{array}{l}\text { Promotion } \\
\text { and } \\
\text { community } \\
\text { empowerment }\end{array}$ & $\begin{array}{l}\text { - Family Welfare } \\
\text { Advisor } \\
\text { - Agency of } \\
\text { Community } \\
\text { Empowerment) } \\
\text { - Elementary School }\end{array}$ & $\begin{array}{l}\text { - The competition of } \\
\text { standby village in } \\
\text { provincial level } \\
\text { - Promotion about the } \\
\text { impacts of smoking } \\
\text { on health and } \\
\text { development of Saka } \\
\text { Bakti Husada (SBH) } \\
\text { and Human Resource } \\
\text { Health Efforts }\end{array}$ \\
\hline 2 & $\begin{array}{l}\text { Community } \\
\text { nutrition } \\
\text { improvement } \\
\text { program }\end{array}$ & $\begin{array}{l}\text { - Local Inspectorate of } \\
\text { South Sulawesi } \\
\text { - Local Board of } \\
\text { Finance Audit } \\
\text { - National Agency of } \\
\text { Drug and Food } \\
\text { Control of Republic } \\
\text { of Indonesia } \\
\text { - Industry and Trade } \\
\text { Office } \\
\text { - Family Welfare } \\
\text { Advisor } \\
\text { - Community and } \\
\text { Village } \\
\text { Empowerment } \\
\text { Agency } \\
\text { - The National Child } \\
\text { Protection } \\
\text { Commission } \\
\text { - Professional } \\
\text { Organization }\end{array}$ & $\begin{array}{l}\text { Based on regulation } \\
\text { Regent regulation } \\
\text { number } 6 \text { of } 2015 \text { and } \\
\text { Governor Regulation } \\
\text { number } 68 \text { of } 2011 \text { and } \\
\text { strengthening networks } \\
\text { and partners to realize } \\
\text { the implementation of } \\
\text { Regent Regulation and } \\
\text { Governor Regulation } \\
\text { about exclusive breast } \\
\text { milk }\end{array}$ \\
\hline 3 & $\begin{array}{l}\text { Improvement } \\
\text { and } \\
\text { development } \\
\text { of planning } \\
\text { and } \\
\text { evaluation } \\
\text { system for } \\
\text { Local } \\
\text { Government } \\
\text { Agency } \\
\text { performance }\end{array}$ & $\begin{array}{ll}\text { - } & \text { Board of Local } \\
\text { Development } \\
\text { Planning } \\
\text { - } \text { Religion Offices } \\
\text { - } \text { Agriculture Offices } \\
\text { - Food Security } \\
\text { Offices } \\
\text { - Board of National } \\
\text { Population and } \\
\text { Family Planning } \\
\text { - Family Welfare } \\
\text { Advisor } \\
\text { - Board of Woman } \\
\text { Empowerment }\end{array}$ & 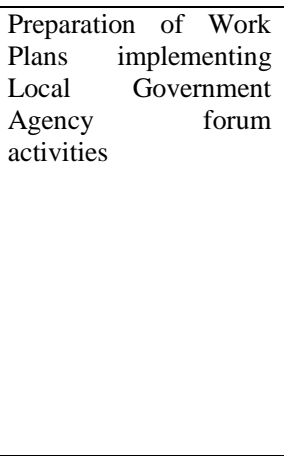 \\
\hline
\end{tabular}

\begin{tabular}{|c|c|c|c|}
\hline 4 & $\begin{array}{l}\text { Public Health } \\
\text { Insurance }\end{array}$ & $\begin{array}{ll}\text { - } & \text { Local Government } \\
& \text { Agency } \\
\text { - Indonesian National } & \text { Health Insurance } \\
\text { - } & \text { Board of Local } \\
\text { Development } \\
\text { Planning } \\
\text { - Social Offices } \\
\text { - Local Government } \\
\text { Finance Offices } \\
\text { - Print and Electronic } \\
\text { Media }\end{array}$ & $\begin{array}{l}\text { Socialization and } \\
\text { advocacy activities to } \\
\text { integrate the health } \\
\text { insurance into The } \\
\text { Indonesian National } \\
\text { Health Insurance } \\
\text { Partnership meeting } \\
\text { Implementation of } \\
\text { public health insurance }\end{array}$ \\
\hline
\end{tabular}

Source: Data processed, 2019

Various programs have been carried out by the South Sulawesi provincial government by involving various sectors, both government and social organizations, but based on the results of the study found that the collaboration has not resulted in an improvement in the health sector optimally. This is due to the service and/or organization involved in the prime health program not fully aware of the importance of programs or activities carried out by the government so that the burden of responsibility is only directed at the technical SKPD. The following are the results of interviews with staff of Ministry of Religion who took part in partnering with the Health Office stating that:

We, from the religious department involved in one of the health service program activities, do realize the importance of basic health socialization, but we have obstacles to always participate in this program because our work units also have other programs, so we cannot be fully involved in health service program (Interview in July 2019. The same thing was said by the staff of the Department of Agriculture about the obstacles in collaborating with the health department ar

That what causes the lack of collaboration that is not maximized is the lack of time for other agencies involved in collaboration as well as the different responsibilities and functions of each which are also different, making it difficult for each of them to hold coordination and routine meetings. In addition, there is also often a change of personnel in each agency/sector involved in a working group on health activities, so it is necessary to adapt and re-socialize in understanding the implementation of the program.

\section{Collaboration of government and JICA}

Table 2: Collaboration of government and JICA

\begin{tabular}{|c|c|}
\hline Activity & $\begin{array}{l}\text { Description of health program activity in } \\
\text { South Sulawesi }\end{array}$ \\
\hline $\begin{array}{l}\text { Memorandum of } \\
\text { Understanding }(\mathrm{MoU})\end{array}$ & $\begin{array}{l}\text { Partnership with three regency: Barru, } \\
\text { Wajo, and Bulukumba }\end{array}$ \\
\hline $\begin{array}{l}\text { Objective of Prime } \\
\text { Health policy }\end{array}$ & Community \\
\hline $\begin{array}{l}\text { Center of Prime Health } \\
\text { activity }\end{array}$ & $\begin{array}{l}\text { Three regency : Barru, Wajo, and } \\
\text { Bulukumba }\end{array}$ \\
\hline $\begin{array}{l}\text { Role types of JICA and } \\
\text { South } \quad \text { Sulawesi } \\
\text { Government program }\end{array}$ & $\begin{array}{l}\text { Prime Health: Enhancement program in } \\
\text { health management capacity of South } \\
\text { Sulawesi, Provide financial assistance in } \\
\text { the form of block grants and technically } \\
\text { assistance, Program assistance in health } \\
\text { development in three regencies }\end{array}$ \\
\hline Goal & $\begin{array}{l}\text { To solve the health problems, especially } \\
\text { infrastructure problems, improving basic } \\
\text { health services, increasing community } \\
\text { involvement in the health sector, } \\
\text { establishing partnership, and cooperation } \\
\text { between various actors in the health } \\
\text { sector }\end{array}$ \\
\hline $\begin{array}{l}\text { Block grant funding for } \\
\text { Prime Health program }\end{array}$ & $\begin{array}{l}\text { The community fund budget sourced from } \\
\text { nongovernmental as follows: } \\
\text { a. Bulukumba: grant funds from Local }\end{array}$ \\
\hline
\end{tabular}




\begin{tabular}{|l|l|}
\hline & $\begin{array}{l}\text { Government Budget and Village } \\
\text { Community Budget }\end{array}$ \\
b. Wajo: Local Government Budget and \\
Village Community Budget \\
c. Barru : Local Government Budget and \\
Village Community Budget
\end{tabular}

Source: Processed from secondary data, 2019

\section{Policy Learning of Health Program in South Sulawesi}

Policy learning, according to Rietig can occur in various conditions. These conditions are (a) when an individual or a group experience a change, (b) when there is a change in knowledge i.e. the individual receives information or rearranges the knowledge he/she has, (c) changes in experience and skills, (d) learning constructivist, which is a combination of the first and second types. In this case, individuals who have gained knowledge about an issue and experienced it directly in practice, and (e) changes in norms, values, and beliefs and basic assumptions held by someone and this change leads to a different way of looking at the world [14] .

In connection with the concept of learning above, the results of this study indicate that there is policy learning in the health sector in Wajo Regency, namely learning policy in the government synergy program between the South Sulawesi Provincial Health Office, Wajo Regency Government, and JICA, which has given birth to the Siaga Prima Mandiri program. This program has involved various institutions in villages and villages with the aim of dealing with problems in the health sector. However, this research found that in general, the activities in the health sector carried out by various forums were not going well, this was still found in various empowerment forums in the basic health sector which were not yet effective in solving basic health problems in Wajo Regency.

A community forum in Wajo Regency which has been formed so far but has not run effectively. Some of the forums that can be mentioned include 1) the Prime Active Standby forum, 2) the Standby-Midd Village forum, 3) the Purnama Standby Village forum. Other forums, namely the Desa Siaga Prima Mandiri forum, are the results of policy learning from three previously formed forums. The following is the description of the institutional forum as follows:

Table 3: Typology of Active Prime Standby Villages in Wajo

RegencyBased on the Development of Policy Learning

Typology of Active Prime Standby Villages in Wajo Regency Based on the Development of Policy Learning

\begin{tabular}{|c|c|c|c|c|}
\hline Criteria & $\begin{array}{l}\text { Pratama } \\
\text { Standby }\end{array}$ & $\begin{array}{l}\text { Midd- } \\
\text { Standby }\end{array}$ & $\begin{array}{l}\text { Purnama } \\
\text { Standby } \\
\end{array}$ & $\begin{array}{ll}\text { Independent } & \text { Prime } \\
\text { Standby } & \\
\end{array}$ \\
\hline $\begin{array}{l}\text { Village } \\
\text { commu } \\
\text { nity } \\
\text { forum }\end{array}$ & $\begin{array}{l}\text { Available } \\
\text { but not } \\
\text { yet in } \\
\text { operation }\end{array}$ & $\begin{array}{l}\text { Has been } \\
\text { operated } \\
\text { but not } \\
\text { routinely }\end{array}$ & $\begin{array}{l}\text { Has been } \\
\text { operated } \\
\text { each three } \\
\text { months }\end{array}$ & $\begin{array}{l}\text { Has been operated } \\
\text { each month }\end{array}$ \\
\hline $\begin{array}{l}\text { Technic } \\
\text { ian }\end{array}$ & $\begin{array}{l}\text { There } \\
\text { have been } \\
\text { two } \\
\text { people but } \\
\text { have not } \\
\text { been able } \\
\text { to provide } \\
\text { services to } \\
\text { all } \\
\text { communit } \\
\text { ies }\end{array}$ & $\begin{array}{l}\text { There } \\
\text { have been } \\
2-3 \text { people } \\
\text { but have } \\
\text { not been } \\
\text { able to } \\
\text { provide } \\
\text { services }\end{array}$ & $\begin{array}{l}\text { There have } \\
\text { been 3-5 } \\
\text { people but } \\
\text { they are not } \\
\text { yet experts } \\
\text { and cannot } \\
\text { provide } \\
\text { services } \\
\text { continuousl } \\
\text { y } \\
\text { (temporary } \\
\text { employees) }\end{array}$ & $\begin{array}{l}\text { There have been } 8 \\
\text { people to provide basic } \\
\text { health services and are } \\
\text { continuously } \\
\text { (permanent } \\
\text { employees) }\end{array}$ \\
\hline $\begin{array}{l}\text { Accessi } \\
\text { bility to } \\
\text { health } \\
\text { services }\end{array}$ & Easy & Easy & Easy & Very easy \\
\hline $\begin{array}{l}\text { Human } \\
\text { Resour } \\
\text { ce } \\
\text { Health } \\
\text { Efforts }\end{array}$ & Inactive & $\begin{array}{l}\text { Not } \\
\text { optimum }\end{array}$ & $\begin{array}{l}\text { Not } \\
\text { optimum }\end{array}$ & Active and optimum \\
\hline $\begin{array}{l}\text { Financi } \\
\text { al } \\
\text { support }\end{array}$ & $\begin{array}{l}\text { There has } \\
\text { been } \\
\text { financial } \\
\text { support } \\
\text { from the } \\
\text { village } \\
\text { governme } \\
\text { nt but not } \\
\text { yet from } \\
\text { communit } \\
\text { y and } \\
\text { non- } \\
\text { governme } \\
\text { ntal } \\
\text { organizati } \\
\text { ons }\end{array}$ & $\begin{array}{l}\text { There has } \\
\text { been } \\
\text { financial } \\
\text { support } \\
\text { from the } \\
\text { village } \\
\text { governme } \\
\text { nt but not } \\
\text { yet from } \\
\text { communit } \\
\text { y and } \\
\text { non- } \\
\text { governme } \\
\text { ntal } \\
\text { organizati } \\
\text { ons }\end{array}$ & $\begin{array}{l}\text { There has } \\
\text { been } \\
\text { financial } \\
\text { support } \\
\text { from the } \\
\text { village } \\
\text { government } \\
\text { and non- } \\
\text { government } \\
\text { al } \\
\text { organizatio } \\
\text { ns } \\
\text { (industry) } \\
\text { but it has } \\
\text { not been } \\
\text { optimal }\end{array}$ & $\begin{array}{l}\text { There has been } \\
\text { financial support from } \\
\text { the village government } \\
\text { and other sources } \\
\text { (community and } \\
\text { business) which have } \\
\text { been carried out } \\
\text { continuously }\end{array}$ \\
\hline $\begin{array}{l}\text { The } \\
\text { role of } \\
\text { the } \\
\text { commu } \\
\text { nity and } \\
\text { commu } \\
\text { nity } \\
\text { organiz } \\
\text { ations }\end{array}$ & $\begin{array}{l}\text { Active } \\
\text { communit } \\
\text { y but not } \\
\text { active } \\
\text { organizati } \\
\text { ons }\end{array}$ & $\begin{array}{l}\text { The } \\
\text { communit } \\
\text { y and } \\
\text { organizati } \\
\text { ons are } \\
\text { active but } \\
\text { not yet } \\
\text { optimum }\end{array}$ & $\begin{array}{l}\text { The } \\
\text { community } \\
\text { and } \\
\text { organizatio } \\
\text { ns are } \\
\text { active but } \\
\text { not yet } \\
\text { optimum }\end{array}$ & $\begin{array}{l}\text { The community has } \\
\text { been active and } \\
\text { initiated partnership } \\
\text { with various } \\
\text { organizations }\end{array}$ \\
\hline
\end{tabular}




\begin{tabular}{|c|c|c|c|c|c|c|c|c|c|}
\hline \multirow{3}{*}{$\begin{array}{l}\text { Regulat } \\
\text { ion of } \\
\text { headma } \\
\mathrm{n} \quad \text { or } \\
\text { regent }\end{array}$} & \multirow[t]{3}{*}{$\begin{array}{l}\text { Unavailab } \\
\text { le }\end{array}$} & \multirow{3}{*}{$\begin{array}{l}\text { Already } \\
\text { exists but } \\
\text { has not } \\
\text { been } \\
\text { realized }\end{array}$} & \multirow{3}{*}{$\begin{array}{l}\text { Already } \\
\text { exists and } \\
\text { has been } \\
\text { realized but } \\
\text { not yet } \\
\text { optimum }\end{array}$} & \multirow{3}{*}{$\begin{array}{l}\text { Already exists and has } \\
\text { been realized Regent } \\
\text { Regulation number } 20 \\
\text { year } 2015 \text { concerning } \\
\text { The Guidelines For } \\
\text { Active Prima Village } \\
\text { Programs, Regent } \\
\text { Regulation number 02 } \\
\text { year } 2016 \text { concerning } \\
\text { Technical Guidelines } \\
\text { for Managing Village } \\
\text { Fund Allocations } \\
\end{array}$} & & & $\begin{array}{l}\text { improvement activities } \\
\text { have been carried out }\end{array}$ & & \\
\hline & & & & & $\begin{array}{l}\text { Cadre } \\
\text { training }\end{array}$ & 16 & $\begin{array}{l}\text { Facilitator training was } \\
\text { conducted for } 205 \text { staff } \\
\text { of Puskesmas and } 65 \\
\text { staff form the Districts } \\
\text { Office through techincal } \\
\text { assistance activities and } \\
\text { community-based health } \\
\text { promotion activities }\end{array}$ & $\begin{array}{l}\text { Posyandu } \\
\text { rehabilitation }\end{array}$ & 15 \\
\hline & & & & & \multirow[t]{2}{*}{\begin{tabular}{|l|} 
CTPS \\
counseling
\end{tabular}} & \multirow[t]{2}{*}{10} & \multirow{2}{*}{$\begin{array}{l}\text { There has been } 27 \text { teams } \\
\text { consisting of } 4 \\
\text { institutions have been } \\
\text { trained as trainers for } \\
\text { Puskesmas/Districts } \\
\text { facilitators for } \\
\text { community-based health } \\
\text { improvement activities }\end{array}$} & \multirow[t]{2}{*}{$\begin{array}{l}\text { Hand-drill } \\
\text { making }\end{array}$} & \multirow[t]{2}{*}{10} \\
\hline $\begin{array}{l}\text { Foundi } \\
\text { ng of } \\
\text { househ } \\
\text { old } \\
\text { PHBS }\end{array}$ & $\begin{array}{l}\text { Coaching } \\
\text { for } \\
\text { minimum } \\
20 \% \text { of } \\
\text { exists } \\
\text { household } \\
\end{array}$ & $\begin{array}{l}\text { Coaching } \\
\text { for } \\
\text { minimum } \\
20 \% \text { of } \\
\text { exists } \\
\text { household }\end{array}$ & $\begin{array}{l}\text { Coaching } \\
\text { for } \\
\text { minimum } \\
40 \% \text { of } \\
\text { exists } \\
\text { household } \\
\end{array}$ & $\begin{array}{l}\text { Coaching for } \\
\text { minimum } 70 \%-80 \% \\
\text { of exists household }\end{array}$ & & & & & \\
\hline \multirow{4}{*}{\multicolumn{5}{|c|}{$\begin{array}{l}\text { The data above shows the presence of a policy learning } \\
\text { process in the implementation of the Prime Health program } \\
\text { in Wajo Regency. The formation of the Village Forum } \\
\text { above has an impact on community empowerment which } \\
\text { results in the birth of community independence in solving } \\
\text { various basic health problems in the community. }\end{array}$}} & & & & $\begin{array}{l}\text { Procurement } \\
\text { of Posyandu } \\
\text { controller }\end{array}$ & 5 \\
\hline & & & & & & & & $\begin{array}{l}\text { Piping } \\
\text { installation }\end{array}$ & 2 \\
\hline & & & & & & & & $\begin{array}{l}\text { Clean water } \\
\text { reservoirs }\end{array}$ & 2 \\
\hline & & & & & & & & $\begin{array}{l}\text { Posyandu } \\
\text { infrastructure }\end{array}$ & 1 \\
\hline \multirow{2}{*}{\multicolumn{5}{|c|}{$\begin{array}{l}\text { The Policy Learning in the Independent Prime Standby } \\
\text { Villages in Wajo Regency, namely: a) the existence of an } \\
\text { independent prima independent alert gave birth to } \\
\text { community empowerment, the revision of local regulations, } \\
\text { b) the running of each program from an independent prima } \\
\text { standalone characterized by the presence of } 8 \text { permanent } \\
\text { employees who provide services in various basic health } \\
\text { fields that are carried out continuously so as to make it easy } \\
\text { for the community to get access to health services, c) the }\end{array}$}} & $\begin{array}{l}\text { Socializatio } \\
\mathrm{n} \text { in districts } \\
\text { and villages }\end{array}$ & & $\begin{array}{l}\text { The socialization about } \\
\text { Regent Regulation } \\
\text { concerning Active } \\
\text { Prime Standby Village }\end{array}$ & & \\
\hline & & & & & $\begin{array}{l}\text { Program } \\
\text { evaluation }\end{array}$ & & 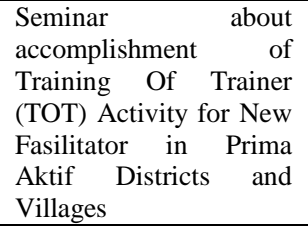 & & \\
\hline
\end{tabular}
running of various health service activities in various health centers and empowerment programs in the village as a result of continuous financial assistance through the Village Fund Budget and supported by a self-help budget from the community each year. The active role of the community encourages partnerships with various social organizations.

The implementation of Siaga Prima Mandiri activities received support from the government through Wajo Regent Regulation number 20 of 2015 regarding The Guidelines For Active Prima Village Programs, causing an increase in PHBS guidance to $80 \%$, more than the previous program. Improvements and developments in various programs such as non-physical activity programs, increasing human resource capacity and increasing development in the field of infrastructure are illustrated in the table below:

Table 4: Learning Typology of Siaga Prima Aktif Village

\begin{tabular}{|c|c|c|c|c|}
\hline \multicolumn{5}{|c|}{ Learning Typology of Siaga Prima Aktif Village } \\
\hline $\begin{array}{l}\text { Non } \\
\text { Physical } \\
\text { Activity }\end{array}$ & $\begin{array}{l}\text { Frequ } \\
\text { ency }\end{array}$ & $\begin{array}{lr}\text { Human } & \text { Resources } \\
\text { Capacity } & \text { Building } \\
\text { Program } & \end{array}$ & $\begin{array}{l}\text { Infrastructure } \\
\text { Development } \\
\text { Program In } \\
\text { The Health } \\
\text { Sector }\end{array}$ & $\begin{array}{l}\text { Frequ } \\
\text { ency }\end{array}$ \\
\hline $\begin{array}{l}\text { Health } \\
\text { counselor }\end{array}$ & 54 & $\begin{array}{l}\text { The community and } \\
\text { work-groups consist of } \\
\text { public and public-figure } \\
\text { who have participated in } \\
\text { training in planning, } \\
\text { implementation, and } \\
\text { accountability } \\
\text { activities so that in all } \\
\text { villages community- } \\
\text { based welfare }\end{array}$ & $\begin{array}{l}\text { Construction } \\
\text { of a health } \\
\text { house }\end{array}$ & 3052 \\
\hline
\end{tabular}

In addition to learning the results of policy typologies, the Desa / Kelurahan Siaga Prima Mandiri program also found learning outcomes as stated by Heclo that policy learning is divided into institutional and socio-political learning. Learning at the institutional level includes ideas between individual learning outcomes and government organizations/institutions related to governance, multi-actor arrangements, with policy entrepreneurs who facilitate cross-institutional learning in issue networks, policy communities, and advocacy coalitions. Socio-political learning refers to a broader area of society at an institutional level through politicians and the media, and on the other hand, public officials, politicians, and non-governmental actors communicate and negotiate in a policy-making network. Through this process, they exchange messages about the desired policy and create momentum for the rational reasons for the policy.

This study found that learning policy on health programs related to the concepts mentioned above can be explained, among others: 1) Instrumental learning found with the issuance of Regent Regulation number 20 of 2015 concerning the implementation and instructions for the Prime Active Village program and changes to the regulations of the Wajo Regent and Regional Regulation number 2 of 2016 concerning technical implementation guidelines for Village Fund Allocation (ADD) management, 2) Social Learning in Independent Prime Villages programs refers to learning related to solving social issues such as social learning outcomes from village programs health prime alert namely the existence of non-physical activity 
programs, capacity building programs, physical / infrastructure development programs in the field of health and human resources, 3) Media Policy Learning in this study includes learning development through routine internal organization activities, such as creating guidebooks, brochures, health education, cadre coaching, socialization in sub-districts and villages, Seminar on achievement of activities, ToT Facilitators of villages / sub-districts / districts of Active Prima, Learning of Prime Standby Villages program policies through learning media. This is consistent with the opinion of Bake (2007) which states that the learning process can take place through socialization or lectures, discussions, dialogues involving stakeholders to discuss various activities or programs related to the implementation of the policy.

In addition to finding a variety of policy learning outcomes as previously described, this study also found that the results of policy learning in the Standby Prime Health program in Wajo District, program implementation was still found to be ineffective. This can be illustrated based on the results of interviews with the community which states that:

"The village fund budget is often delayed so that some health service activities are still ineffective, even though the local government has issued a local regulation on the village budget (ADD), so it is also found that local government actors in implementing the existing programs are still less active in providing learning policies in accordance with their duties and responsibilities. Such as regulatory and supervisory functions are still not optimum in monitoring every activity program in villages and sub-districts in Wajo district[15]"

This is similarly stated by Heclo that in policy learning there is usually the possibility of non-learning situations, namely situations where policymakers and public institutions do not wish or have the ability to adapt to new information [16].

\section{CONCLUSION}

There is a collaborative collaboration between the Provincial Government of South Sulawesi, Regency / City Governments and JICA in prime health programs in the Province of South Sulawesi. There is a significant Policy Learning in developing the Prime Health program in South Sulawesi Province. Collaboration needs to be developed in the implementation of prime health programs in South Sulawesi Province. It needs to be optimized and developed continuously related to policy learning in the success of a government program, especially the public health improvement program.

\section{ACKNOWLEDGMENT}

Special appreciation also given to all informants who are faithfully sharing valuable information to us so that all data needed in the research can be collected.

\section{REFERENCES}

[1] J. Defourny and M. Nyssens, "Social enterprise in Europe: recent trends and developments," Soc.
Enterp. J., 2008.

[2] L. Gilson, P. D. Sen, S. Mohammed, and P. Mujinja, "The potential of health sector non-governmental organizations: policy options," Health Policy Plan., vol. 9, no. 1, pp. 14-24, 1994.

[3] M. A. Ibrahim, "Framework Model in Implementation of Spatial Policy in Makassar City (Framework Model in Implementation of Spatial Policy Change of Makassar City)," Asian Soc. Sci., vol. 10, no. 18, p. 37, 2014.

[4] J. E. Grunig, "Furnishing the edifice: Ongoing research on public relations as a strategic management function," J. Public relations Res., vol. 18, no. 2, pp. 151-176, 2006.

[5] N. Nursini, A. Agussalim, S. Suhab, and T. Tawakkal, "Implementing Pro Poor Budgeting in Poverty Reduction: A Case of Local Government in Bone District, South Sulawesi Province, Indonesia," Int. J. Econ. Financ. Issues, vol. 8, no. 1, p. 30, 2018.

[6] F. Ahmadi and A. Triwinarto, "Analysis descriptive stunting in Indonesia Health Research Basic," Ann. Trop. Med. Heal., vol. 22, pp. 472-477, 2019.

[7] M. Hartlapp, "Learning about policy learning: Reflections on the European employment strategy," Eur. Integr. online Pap. (EIoP), Spec., no. 1, 2009.

[8] H. Heclo, Modern social politics in Britain and Sweden. ECPR Press, 2010.

[9] S. Funtowicz and J. Ravetz, "Post-normal science," Int. Soc. Ecol. Econ. (ed.), Online Encycl. Ecol. Econ. http//www. ecoeco. org/publica/encyc. htm, 2003.

[10] J. W. Creswell and J. D. Creswell, Research design: Qualitative, quantitative, and mixed methods approaches. Sage publications, 2017.

[11] R. K. Yin, Qualitative research from start to finish. Guilford publications, 2015.

[12] W. N. Suter, "Qualitative data, analysis, and design," Introd. to Educ. Res. A Crit. Think. approach, vol. 2, pp. 342-386, 2012.

[13] M. Kasiram, "Metodologi penelitian: Kualitatifkuantitatif." Uin-Maliki Press, 2010.

[14] D. J. Van de Kaa, "Postmodern fertility preferences: from changing value orientation to new behavior," Popul. Dev. Rev., vol. 27, pp. 290-331, 2001.

[15] I. N. Basri, "ANALYZING THE QUALITY OF WORK PROGRAMS IN MANGGALA DISTRICT, MAKASSAR CITY, SOUTH SULAWESI PROVINCE, INDONESIA, BETWEEN 2014-2019," Soc. Clim. Chang. 5.0 Soc., p. 124.

[16] S. Moyson, "The individual in policy change: Policy learning in the liberalization of network industries in Belgium," Unpubl. PhD Diss. Univ. Cathol. Louvain, Belgium, 2014. 